\title{
To slide or stride: when should Adélie penguins (Pygoscelis adeliae) toboggan?
}

\author{
Rory P. Wilson, ${ }^{1}$ Boris Culik, And Dieter Adelung \\ Institut für Meereskunde an der Universität Kiel, Düsternbrooker Weg 20, D-2300 Kiel 1, Federal Republic of Germany \\ AND \\ N. Ruben Coria and Hugo J. Spairani \\ Instituto Antartico Argentino, Cerrito 1248 (1010), Buenos Aires, Argentina
}

Received June 20, 1989

\begin{abstract}
Wilson, R. P., Culik, B., Adelung, D., Coria, N. R., and Spairani, H. J. 1991. To slide or stride: when should Adélie penguins (Pygoscelis adeliae) toboggan? Can. J. Zool. 69: 221-225.

We noted whether Adélie penguins (Pygoscelis adeliae), when travelling over snow, walked or tobogganed according to gradient, snow friction, or snow penetrability. Both walking and tobogganing penguins reduced stride length and stride frequency, and thus speed, with increasing uphill gradient although tobogganing birds travelled faster and with fewer leg movements. The incidence of tobogganing increased with decreasing friction between penguin and snow. The percentage of penguins tobogganing was also highly positively correlated with increasing snow penetrability. Penguins walking on soft snow must expend additional energy to pull their feet through the snow, whereas tobogganing birds do not sink. It is to be expected that Adélie penguins would utilize the most energetically favourable form of travel which, under almost all conditions, appeared to be tobogganing. Although tobogganing appears to be energetically more efficient than walking, rubbing the feathers over snow increases the coefficient of friction in unpreeened plumage. We propose that a high incidence of tobogganing necessitates increased feather care and that the decision whether to walk or toboggan probably represents a balance between immediate energy expenditure and subsequent energy and time expended maintaining plumage condition.
\end{abstract}

Wilson, R. P., Culik, B., Adelung, D., Coria, N. R., et Spairani, H. J. 1991. To slide or stride: when should Adélie penguins (Pygoscelis adeliae) toboggan? Can. J. Zool. 69 : 221-225.

Nous avons cherché à déterminer si les Manchots d'Adélie (Pyqoscelis adeliae) qui se déplacent sur la neige marchent ou se laissent glisser en fonction de la pente, de la friction de la neige ou de sa pénétrabilité. Qu'ils marchent ou qu'ils se laissent glisser, les manchots réduisent la longueur et la fréquence de leurs pas, donc leur vitesse, en fonction de l'importance d'un gradient ascendant, bien que les manchots glisseurs se déplacent plus rapidement et en utilisant moins de mouvements de pattes. L'utilisation des glissades augmente lorsque la friction entre l'animal et la neige diminue. Le pourcentage de manchots glisseurs augmente considérablement en fonction de l'augmentation de la pénétrabilité de la neige. Les manchots qui marchent sur la neige molle doivent déployer beaucoup plus d'énergie, car ils doivent retirer leurs pattes de la neige, alors que les manchots glisseurs ne s'enfoncent pas. Il est logique de penser que les manchots utilisent toujours la forme la plus économique de déplacement qui semble, dans toutes les conditions, être l'utilisation de glissades. Bien que les glissades semblent plus avantageuses que la marche du point de vue énergétique, le frottement des plumes sur la neige augmente le coefficient de friction du plumage non lissé. Nous croyons que l'utilisation fréquente des glissades nécessite un toilettage plus intense des plumes et que la décision de marcher ou de glisser résulte probablement d'un compromis entre la dépense énergétique immédiate et la dépense d'énergie et de temps encourue plus tard dans l'entretien du plumage.

[Traduit par la revue]

\section{Introduction}

Although emperor penguins, Aptenodytes forsteri, and Adélie penguins, Pygoscelis adeliae, are highly specialized for an aquatic existence, they have been known to travel more than $100 \mathrm{~km}$ from the sea to reach nesting areas (Sladen 1960; Sladen and Ostenso 1960; Stonehouse 1960; Budd 1962). While on land, penguins normally walk or toboggan. Walking is a relatively energetically costly mode of travel (Pinshow et al. 1976; Dewasmes et al. 1980; Le Maho and Dewasmes 1984), since with each step penguins undergo large lateral displacements ("waddling" sensu Pinshow et al. 1977). Walking penguins are inefficient compared with other birds, probably because penguins have a morphology primarily adapted to underwater locomotion (Fedak et al. 1974). However, the fusiform body shape of penguins adapted for optimal underwater travel enables them to slide easily over low-friction surfaces. Antarctic penguins can travel faster by tobogganing than by running (Pinshow et al. 1977). Tobogganing penguins lie on their belly and, with alternating foot movements, push themselves forwards. The flippers may be used to assist (Sladen 1958; Prevost and Sapin-Jaloustre 1965). Our observations indicate that Adélie penguins tobogganing on flat snow surfaces push only with their feet. When climbing slopes greater than ca.

\footnotetext{
${ }^{1}$ Author to whom all correspondence should be sent.

$15^{\circ}$, particularly when the snow is soft, the birds may also use their flippers. Birds tobogganing down slopes use their feet to a lesser extent with increasing downhill slope until gradients of about $15^{\circ}$, when the feet may be used as a brake.

Adélie penguins tend to toboggan on ice or over "difficult" surfaces such as fresh snow or broken ice (Prevost and Sapin-Jaloustre 1965). Penguins moving long distances over snow alternate tobogganing with walking (Prevost and SapinJaloustre 1965). Although temperate-zone penguins do not usually toboggan (e.g. , Boersma 1976), possibly due to the lack of a suitable surface, many species will toboggan if alarmed (Boersma 1976).

The switch between walking and tobogganing implies that the optimum method of locomotion changes according to environmental conditions. We investigated the incidence and efficiency of walking and tobogganing in Adélie penguins in relation to snow conditions - softness, friction, and gradient - to examine whether birds utilize the two methods of locomotion according to which is energetically the most favourable.

\section{Methods}

All fieldwork was conducted near the Argentinian base at Esperanza Bay $\left(63^{\circ} 24^{\prime} \mathrm{W}, 56^{\circ} 59^{\prime} \mathrm{S}\right)$ at the tip of the Antarctic Peninsula, between 20 and 30 November 1987.

We watched Adélie penguins moving between the sea and their 
nesting areas over a sheltered snow field. Snow had fallen 2 days before our study started and the surface appeared to be homogeneous. Since birds in adjacent colonies were incubating eggs, relatively few individuals passed over the snow field and no trails were apparent. No snow fell during the study period. The area measured ca. $450 \times 150 \mathrm{~m}$ and comprised slopes ranging in gradient from $0^{\circ}$ to $14^{\circ}$. Sections of the field, $10 \times 10 \mathrm{~m}$, consisting of smooth slopes were marked by four upright poles so that two poles were at one specific altitude and two at another. For each marked area, observers were placed at a point equidistant, but $>20 \mathrm{~m}$, from two poles at different altitudes. We watched penguins moving through the marked quadrats perpendicular to the line of sight. For any birds that completed the course without pausing, deviating, or changing mode of locomotion we noted the method of locomotion (toboggan or walk), the number of nearest-side foot movements (strides: single steps for walking birds or single leg pushes for tobogganing birds), and the time taken to complete the $10-\mathrm{m}$ course. The gradients of the slopes were determined using levels and simple trigonometry.

For 3 days we made counts of the total number of penguins tobogganing and walking over the snow field. Concomitant measurements were made of snow condition. Snow penetrability was determined approximately by placing the end of a $5-\mathrm{kg}$ rod (end surface area $3850 \mathrm{~mm}^{2}$ ) on a level snow surface. The rod was intended to simulate a penguin foot exerting a pressure on the surface equivalent to that of an adult penguin standing on one foot (see later). The rod was allowed to sink into the snow until it stopped moving, and the depth of penetration was measured. This process was repeated 5 times to derive mean snow penetrability values for each time period.

We also estimated the friction between the snow and a prostrate penguin. Initially, we anaesthetized an adult Adélie penguin (mass $4.45 \mathrm{~kg}$ ) with ketamine (Ketalar (50 mg ketamine hydrochloride $/ \mathrm{cm}^{3}$ ); $0.9 \mathrm{~cm}^{3}$ injected intramuscularly) and attached string to the tip of the bill. The other end of the string was fixed to a spring balance (1000 or $5000 \mathrm{~g}$ ). We placed the bird on level snow and dragged it forwards via the spring balance, keeping the string parallel to the ground and noting the maximum force required to overcome friction $\left(\phi_{\max }\right.$, the force exerted to just initiate movement; $\phi_{\max }$ is related to the coefficient of friction between the two surfaces, $\mu$, by $\phi_{\max }=\mu, R$, where $R$ is the normal push of the snow on the penguin). This process was repeated 20 times to derive a mean value. This procedure was repeated with a freshly killed adult Adélie penguin (mass $4.6 \mathrm{~kg}$ ). Since there was no difference in $\phi_{\max }$ between the live and dead birds (see later), the dead bird was then used to determine mean values for $\phi_{\max }$ during subsequent trials. We considered it unnecessary to kill more than one bird for these determinations, since we were measuring a purely physical parameter where variability in behavioural and physiological responses was not an issue. Between measurements, in an attempt to simulate conditions experienced by breeding penguins, the bird was stored outside on a bed of pebbles. Normally, penguins maintain plumage condition by preening. By measuring $\phi_{\max }$ in a freshly killed bird over a number of trials we also hoped to detect changes in the coefficient of friction $(\mu)$ resulting from feather deterioration due to the lack of preening of feathers exposed to wear. For comparison we also measured $\phi_{\max }$ for a penguin being pulled backwards and for a penguin that had been dead for some weeks (mass $4.2 \mathrm{~kg}$ ) and consequently had deteriorated plumage.

The approximate surface area of an Adélie penguin foot in contact with the ground was determined by tracing round a foot on graph paper and counting the squares. The approximate surface area of a tobogganing Adélie penguin in contact with the snow was measured by placing the freshly killed bird on the snow. Mean penetrability at that time, as determined by the $5-\mathrm{kg}$ rod (see earlier), was $78 \pm 12$ (SD) $\mathrm{mm}, n=$ 10). The ovoid depression produced by the bird's body was traced and the area determined by counting graph-paper squares.

On November 24, we discovered that one level section of snow, not used in any previous observations, was composed of two different snow types: hard and soft (penetration values $3.2 \pm 1.1$ and $150 \pm$ $17 \mathrm{~mm}$, respectively). During a 4-h period we noted the total number of birds walking and tobogganing across the different surfaces.

Correlations were examined with coefficients of determinations, the
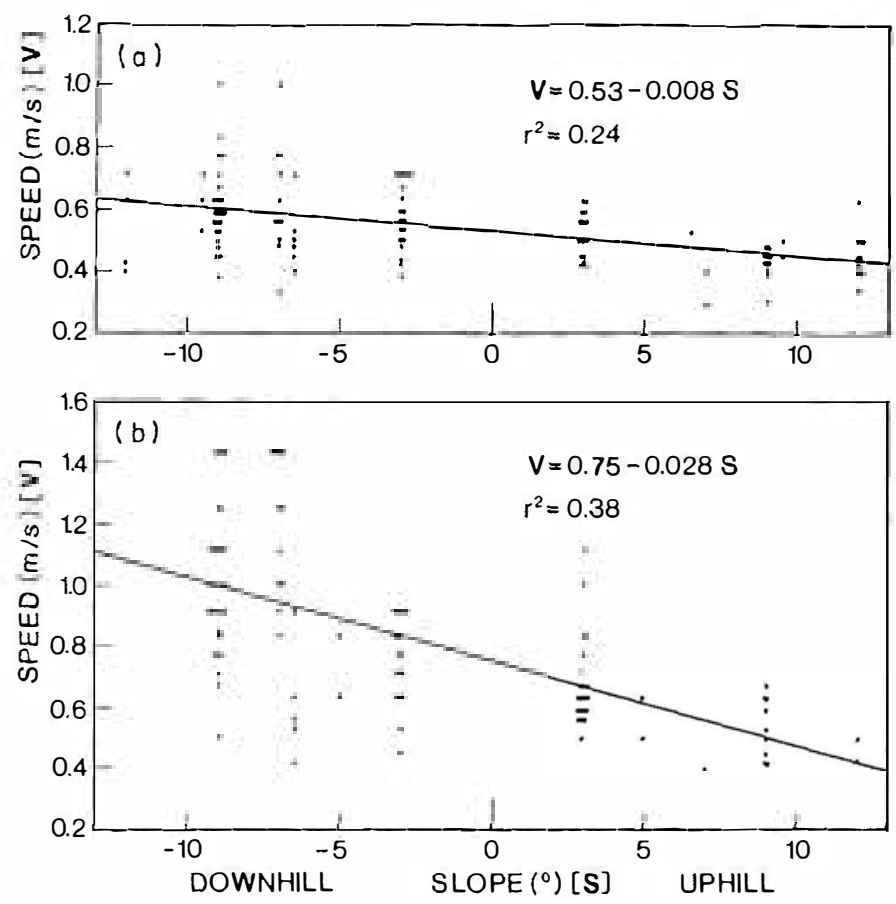

FIG. 1. Relationship between travelling speed and gradient for free-living Adélie penguins moving over a $10-\mathrm{m}$ course on snow without pausing (a) Walking birds. (b) Tobogganing birds.

slope significances being determined by calculating $F$ values and using $P$ values of $<0.05$ (Zar 1984). All percentage data used in correlations were normalized by means of arcsine transformations. Statistical differences between means were determined using $t$-tests with $P$ values of $<0.05$.

\section{Results}

There was a significant correlation between travelling speed (metres per second) and slope (degree) for both walking and tobogganing penguins $\left(F_{[1,119]}=35.45, P<0.001\right.$, and $F_{[1,110]}=40.43, P<0.001$, respectively) (Fig. 1). In both cases, travelling speed increased as the downhill slope increased, although tobogganing birds travelled faster than walking birds over the entire range of gradients used. For walking birds, changes in speed associated with different gradients were brought about by changes in stride frequency (strides/s) $\left(F_{[1,113]}=10.92, P<0.001\right.$; Fig. 2) and in stride length. The number of steps taken per $10 \mathrm{~m}$ significantly changed as a function of slope in both walking and tobogganing penguins $\left(F_{[1,115]}=8.64, P<0.01\right.$, and $\left(F_{[1,78]}=181.3\right.$, $P<0.001$, respectively) (Fig. 3), with birds taking fewer steps per $10 \mathrm{~m}$ with increasing downhill slope.

There was no apparent correlation between the percentage of penguins tobogganing (arcsine transformed) and slope (for values where the total number of penguins either walking or tobogganing was greater than five) $\left(F_{[1,5]}=1.07, P>0.1\right.$, and $F_{[1,5]}=2.95, P>0.1$ for negative and positive slopes, respectively).

During the course of the study the mean snow penetrability varied between $3.2 \pm 1.1$ and $211 \pm 15 \mathrm{~mm}$. During the $4 \mathrm{~h}$ when penguins were observed travelling across an area of hard and soft snow, 35 birds walked and 2 tobogganed on the hard snow and 21 birds tobogganed while none walked on the soft snow. Penguins thus tobogganed more frequently on the soft snow and walked more frequently on the hard snow than expected by chance $\left(\chi^{2}=50.1\right.$, df $\left.=1, P<0.001\right)$. The 


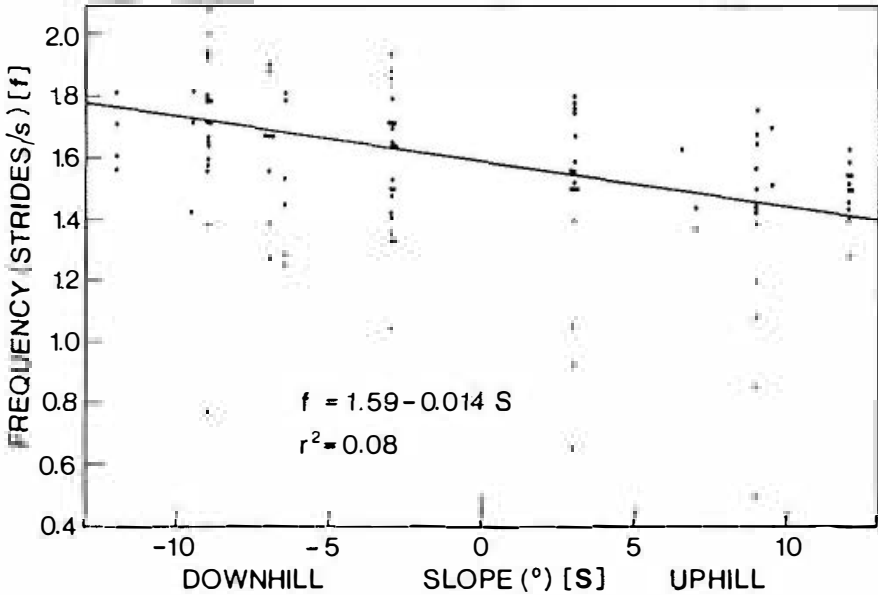

FIG. 2. Relationship between stride frequency and gradient for free-living Adélie penguins walking over a $10-\mathrm{m}$ course on snow without pausing.
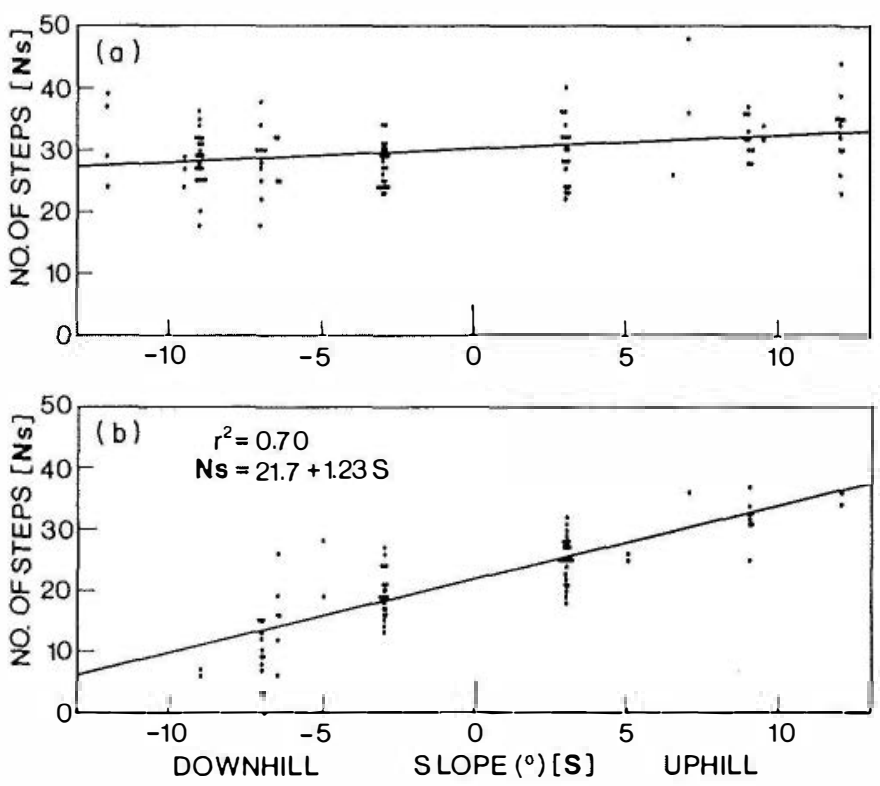

FIG. 3. Relationship between the number of strides taken by walking Adélie penguins $(a)$ and foot movements (strides) made by tobogganing Adélie penguins $(b)$ per $10 \mathrm{~m}$ in relation to gradient.

percentage of penguins tobogganing significantly increased as a $\log$ function of increasing snow penetrability (in millimetres) $\left(F_{[1,23]}=22.09, P<0.001\right)$ (Fig. 4). The percentage of penguins tobogganing also increased significantly as the friction between penguin and snow $(\mathrm{N})$ decreased $\left(F_{[1,24]}=6.83, P<\right.$ $0.05)$ (Fig. 5). There was no correlation between snow penetrability and friction $\left(F_{[1,23]}=0.58, P>0.1\right)$.

Friction $\left(\phi_{\max }\right)$ was significantly greater when birds were pulled backwards rather than forwards (mean $\phi_{\max }$ values $37.0 \pm 6.1 \mathrm{~N}, n=20$, and $7.0 \pm 1.4 \mathrm{~N}, n=20$, respectively; $t=21.44, P<0.001)$. The anaesthetized and freshly killed penguins did not have significantly different $\phi_{\max }$ values $(\bar{x} \pm$ SD $6.3 \pm 1.0 \mathrm{~N}, n=20$, and $\bar{x} \pm \operatorname{SD} 5.77 \pm 1.5 \mathrm{~N}, n=20$, respectively; $t=1.38, P>0.05$ ); however, the freshly killed penguin had a significantly lower $\phi_{\max }$ than the long-dead bird with deteriorated plumage $(\vec{x} \pm$ SD $14.3 \pm 3.2 \mathrm{~N}, n=20$; $t=10.72, P<0.001)$. The condition of the ventral feathers of the killed bird appeared to be deteriorate during the $\phi_{\max }$

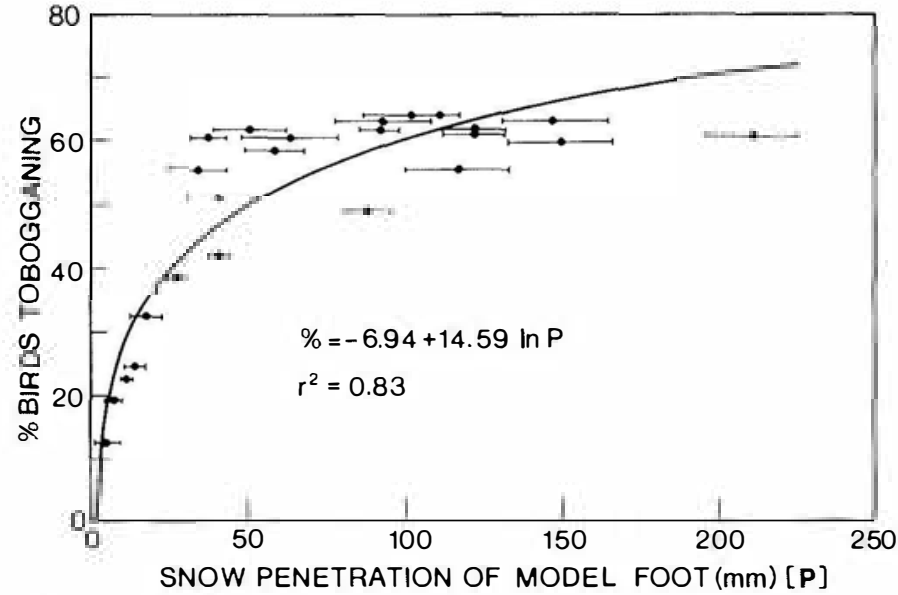

FIG. 4. Relationship between the percentage of Adélie penguins tobogganing (arcsine transformed) and snow softness (as determined by the penetration of a model penguin foot; see text). Data points show means and horizontal bars indicate standard deviation.

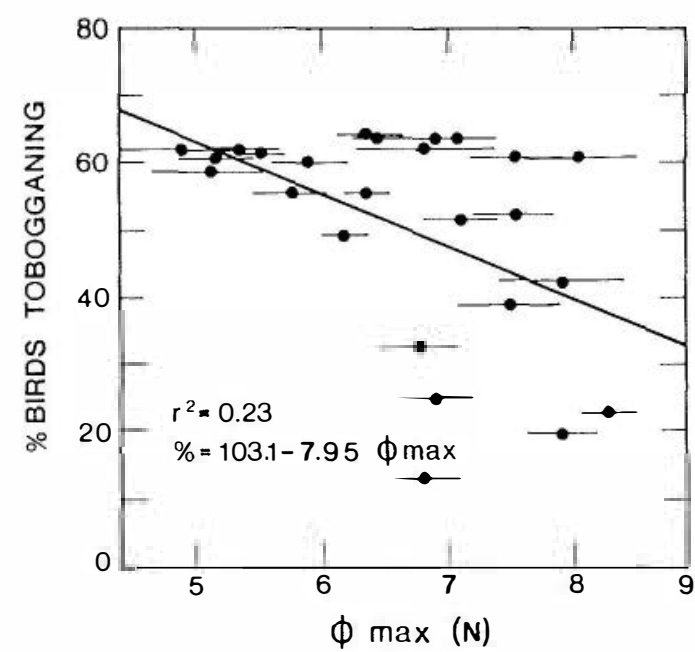

FIG. 5. Relationship between the percentage of Adélie penguins tobogganing (arcsine transformed) and the force necessary to overcome friction $\left(\phi_{\max }\right)$ between a prone penguin and the snow. Data points show means derived from 20 readings and horizontal bars indicate standard error.

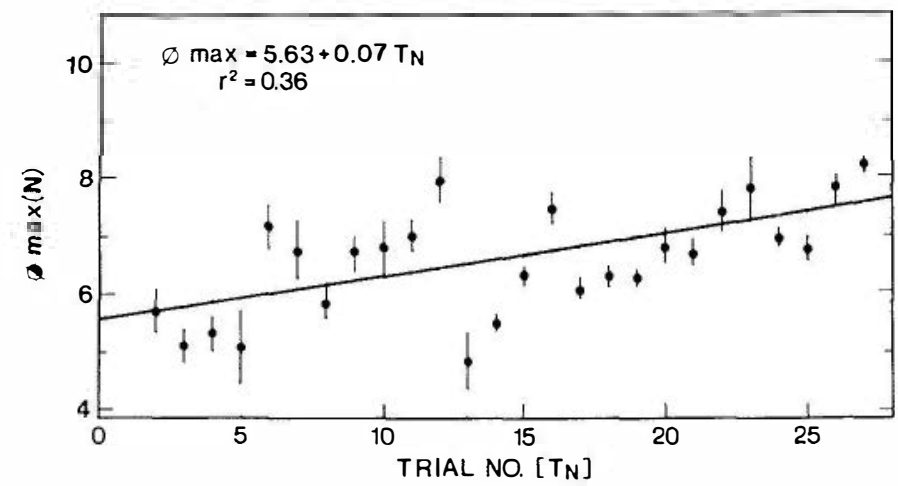

FIG. 6. Relationship between the force necessary to overcome friction $\left(\phi_{\max }\right)$ between a freshly killed Adélie penguin and the snow and the number of $\phi_{\max }$ determination trials. Each trial comprised 20 readings. Data points show means and horizontal bars indicate standard error. 


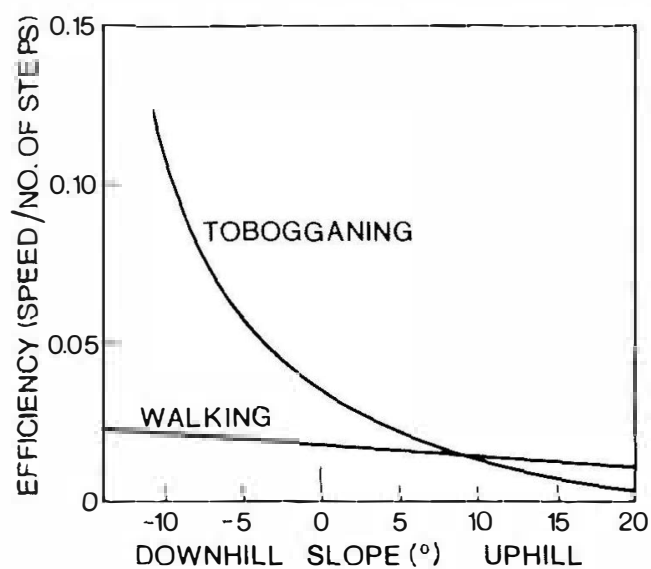

FIG. 7. Efficiency (speed/number of foot movements) of tobogganing and walking Adélie penguins in relation to gradient. The equations relating speed and number of foot movements to gradient are derived from Figs. 1 and 3.

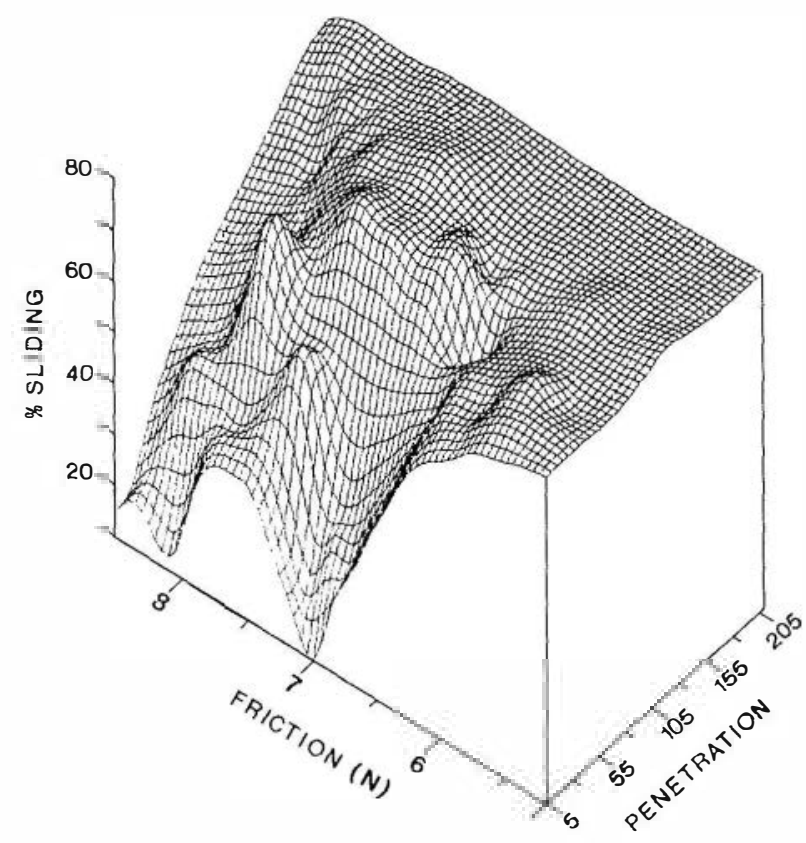

FIG. 8. Relationship between the percentage of penguins tobogganing, snow penetrability, and friction $\left(\phi_{\max }\right)$. The sheet represented was computed by interpolation of the data points.

determinations. Concomitantly, the friction between penguin and snow increased significantly with the number of trials $\left(F_{[1,25]}=13.35, P<0.005\right.$; Fig. 6$)$.

The surface area of the prostrate penguin in contact with the snow (penetrability $78 \mathrm{~mm}$, see earlier) was ca. $18000 \mathrm{~mm}^{2}$. The surface area of the Adélie penguin's foot in contact with the ground was approximately $2550 \mathrm{~mm}^{2}$.

\section{Discussion}

The hydrodynamic pressures acting on high-speed swimming marine animals tend to make their bodies fusiform. This shape allows marine animals that have a terrestrial phase (e.g., seals) to slide over smooth surfaces relatively easily, the ef ficiency of the mechanism depending on the nature and slope of the terrain.

Penguins, besides being able to toboggan, can walk with legs that are set far back and so essentially do not interfere with streamlining. The decision whether to walk or toboggan is likely to result from an attempt to minimize energy expenditure.
We could not quantify the energy used in leg movements (strides) for penguins walking and tobogganing. Our subjective impression is that tobogganing birds use less energy per leg movement than walking birds. The theoretical case where the cost of a single foot movement is the same for both walking and tobogganing birds indicates that it is energetically more efficient (where efficiency $=$ speed/number of strides per unit distance) to toboggan than walk at all negative slopes and positive slopes less than about $7^{\circ}$ (Fig. 7; data derived from Figs. 1 and 3). Whatever the relative costs of foot movements for walking and tobogganing birds, the basic form of the efficiency versus slope graph will remain the same because at some negative slopes it is unnecessary for tobogganing penguins to push with their feet at all. In general, with increasing negative gradient, tobogganing becomes exponentially more efficient than walking. Physical factors that might change the energetics of the two forms of locomotion are snow penetrability, gradient, friction, wind, and possibly stomach load.

We have eliminated wind from our discussion because the snow field was very sheltered. Although our study birds were not feeding chicks, and were therefore unlikely to have a very full stomach (Puddicombe and Johnstone 1988), birds with a substantial stomach load will exert a greater pressure on the snow than conspecifics with an empty stomach. We could not quantify this without unacceptable disturbance, so we use mean penguin mass in our calculations.

\section{Snow penetrability, gradient, and friction}

Adélie penguins have an approximate mean mass of $5 \mathrm{~kg}$ (range 3.3-6.5 kg; Stonehouse 1975). Since the surface area of the sole of an Adélie penguin foot is ca. $2550 \mathrm{~mm}^{2}$, the bird exerts a pressure of $0.019 \mathrm{~N} \cdot \mathrm{mm}^{-2}$ (range $0.013-$ $0.025 \mathrm{~N} \cdot \mathrm{mm}^{-2}$ ) on the ground when resting on one leg. When a walking penguin steps off ice onto soft snow the leading foot will sink beneath the surface to a depth determined by the pressure exerted via the bird's mass. During the subsequent step the leading foot will sink deeper because, in this case, the downward force will result from the mass of the penguin plus the downward force used to counteract the force necessary to pull the hindmost leg out of the snow. Ultimately, the depth to which the feet sink will become constant because the force necessary to pull the foot out of the snow plus the force imposed as a result of the bird's mass will cause the foot under pressure to sink to the same depth as the foot being lifted. Thus, penguins walking on snow into which they penetrate have to expend additional energy to pull their feet out of the snow with every pace, and this energy is partially used to sink the proximal foot.

The situation is complicated when penguins walk on snow slopes. Adélie penguins appear to decrease their stride frequency and stride length to reduce their speed and work rate as the upward gradient increases (cf. Cavagna et al. 1964; Cavagna and Margaria 1966; Taylor et al. 1972). However, the precise way in which the ambulatory frequency and stride length change with respect to gradient will presumably determine the likelihood that the penguins will break through the snow surface, since pressures will change accordingly.

If walking penguins do sink in the snow, it appears that they favour tobogganing as a method of travel. The reduced pressure exerted on the snow due to the increased surface area projected by a prone penguin means that sliding birds do not sink appreciably. Theoretically, it will also become relatively easier to toboggan as friction decreases, and correspondingly, Adélie penguins in our study tobogganed more when the friction was lower (Figs. 5 and 8). The incidence of birds tobogganing over 
smooth ice is also reported to be high (Prevost and SapinJaloustre 1965).

Gradient changes will have a considerable effect on the force that penguins must exert to toboggan. A bird of mass $M$ and an $\phi_{\max }$ value depending on snow conditions (Fig. 5) will have to exert a force of $9.8 M \sin S-\phi_{\max }$ (where $S$ is slope) to initiate movement downhill. Theoretically our freshly killed Adélie penguin $\left(\phi_{\max }=5.7 \mathrm{~N}\right)$ would just begin to slide downhill at a gradient of $7.2^{\circ}$. The friction against penguins being pulled backwards will prevent backward slippage on any slope up which Adélie penguins may toboggan (up to $55^{\circ} ; \phi_{\max }$ for penguin being pulled backwards $=37 \mathrm{~N}$ ).

Overall, the apparent energetic efficiency of tobogganing compared with walking, especially for birds moving downhill, implies that Adélie penguins should almost always slide (Fig. 7). This is clearly not the case, suggesting that factors other than immediate energetics are important.

The laws of solid friction state that $\phi_{\max }$ (and hence $\mu$, since $R$ in our experiment is constant) is controlled by the material composition and cleanliness of the surfaces in contact and not by the common surface area. Thus, observed changes in $\phi_{\max }$ during our trials are due to changes in either the snow surface or the penguin feather surface. The increasing $\phi_{\max }$ with increasing trial number indicates that a change in penguin feather condition tends to reduce sliding efficiency. This is substantiated by the high $\phi_{\max }$ values for the long-dead bird. We propose that changes in two elements of feather condition may be responsible for this. Rubbing the breast over the snow during tobogganing may accelerate the loss of oil from the ventral feathers, in which case time would have to be invested in preening. We were unable to examine this because although Adélie penguins spend considerable time preening (personal observations), much of it is done at sea and is not quantifiable. Alternatively, tobogganing may result in direct feather wear, which cannot be rectified until the annual moult (Ryan et al. 1987). Since feather condition is crucial for fast, efficient swimming in penguins (Nachtigall and Bilo 1980; Wilson 1985), permanent feather damage may reduce swimming performance. Again, this is difficult to quantify in the field. Paradoxically, if this is the case, the fusiform body shape of penguins, resulting from hydrodynamic optimization in the water, may allow these birds to move efficiently on land by sliding, but in doing so they may compromise their efficiency in the water.

In conclusion, Adélie penguins appear to save energy by tobogganing when walking is relatively energetically costly due to soft or slippery snow. However, if penguins are optimizing energy requirements, there must be a reason why birds moving downhill do not toboggan more often. Deterioration of feather condition may account for this, but other factors, e.g., enhanced visual contact with conspecifics or enhanced navigation, may also be relevant. Future work is needed to address this more fully.

\section{Acknowledgements}

We thank the Instituto Antartico Argentino for providing logistic support. Funding was provided by the Deutsche Forschungsgemeinschaft grant MZ/Ad 24/11-1. We are grateful to G. L. Kooyman, M.-P. Wilson, and M. Kersten for comments on the manuscript and A. Eisele for preparing the figures.

Boersma, P. D. 1976. An ecological and behavioral study of the Galapagos Penguin. Living Bird, 15: 43-93

Budd, G. M. 1962. Population studies in rookeries of the Emperor Penguin, Aptenodytes forsteri. Proc. Zool. Soc. Lond. 139: 365388.

Cavagna, G. A., and Margaria, R. 1966. Mechanics of walking. J. Appl. Physiol. 21: 271-278.

Cavagna, G. A., Saibene, F. P., and Margaris, R. 1964. Mechanical work in running. J. Appl. Physiol. 19: 249-256.

Dewasmes, G., LeMaho, Y., Cornet, A., and Groscolas, R. 1980. Resting metabolic rates and cost of locomotion in long-term fasting Emperor Penguins. J. Appl. Physiol. 49: 888-896.

Fedak, M., Pinshow, B., and Schmidt-Nielsen, K. 1974. Energy cost of bipedal running. Am. J. Physiol. 227: 1038-1044.

Le Maho, Y., and Dewasmes, G. 1984. Energetics of walking in penguins. In Seabird energetics. Edited by G. C. Whittow and H. Rahn. Plenum Publishing Corp., New York and London. pp. 235-243.

Nachtigall, W., and Bilo, D. 1980. Strömungsanpassung der Pinguine beim Schwimmen unter Wasser. J. Comp. Physiol. A, 137: 17-26.

Pinshow, B., Fedak, M. A., Battles, D. R., and SchmidtNIELSEN, K. 1976. Energy expenditure for thermoregulation and locomotion in Emperor Penguins. Am. J. Physiol. 231: 903-912.

Pinshow, B., Fedak, M. A., and Schmidt-Nielsen, K. 1977. Terrestrial locomotion in penguins: it costs more to waddle. Science (Washington, D.C.), 195: 592-594.

Prevost, J., and SAPIN-Jaloustre, J. 1965. Écologie des manchots Antarctiques. In Biogeography and ecology in Antarctica. Edited by J. Van Mieghem, P. Van Oye, and G. Schell. Monographiae Biologicae. Vol. 15. Dr. W. Junk bv, The Hague. pp. 551-648.

Puddicombe, R. A., and Johnstone, G. W. 1988. The breeding season diet of Adélie penguins at the Vestfold Hills, East Antarctica. Hydrobiologia, 16: 239-253.

Ryan, P. G., Wilson, R. P., and CoOper, J. 1987. Intraspecific mimicry and status signals in juvenile African penguins. Behav. Ecol. Sociobiol. 20: 69-76.

Sladen, W. J. L. 1958. The pygoscelid penguins. 1. Methods of study. 2. The Adélie Penguin. Falkl. Isl. Depend. Surv. Sci. Rep. 17: $1-97$.

St.aden, W. J. L., and Ostenso, N. A. 1960. Penguin tracks far inland in the Antarctic. Auk, 77: 466-469.

Stonenouse, B. 1960. The King Penguin Aptenodytes patagonica of South Georgia Island: breeding behaviour and development. Falkl. Isl. Depend. Surv. Sci. Rep. 23: 1-81.

1975. Introduction: the Spheniscidae. In The biology of penguins. Edited by B. Stonehouse. Macmillan Press, London.

Taylor, C. R., Caldwell, S. L., and Rowntree, V. J. 1972. Running up and down hills: some consequences of size. Science (Washington, D.C.), 178: 1096-1097.

WILsON, R. P. 1985. The Jackass Penguin (Spheniscus demersus) as a pelagic predator. Mar. Ecol. Progr. Ser. 25: 219-227.

ZAR, J. H. 1984. Biostatistical analysis. Prentice Hall, Englewood Cliffs, NJ. 